\title{
Participation in Reproductive Health Policies in the Context of Health System Reform in Mexico
}

\author{
Jesica Gómez-Jauregui
}

\begin{abstract}
1 Introduction
One of the core aims of Mexico's health sector reform in the two last administrations has been the extension of essential health services to the whole population. In order to reach that aim, concrete measures have been proposed within the National Health Plans (Planes Nacionales de Salud). Those measures aim at extending coverage in three distinct ways: (1) by incrementing the percentage of the population that receive the services; (2) by incrementing the number of services provided to the bulk of the population; and (3) by taking the services to geographic areas or groups that had no access to them (Gómez-Dantés et al. 2004; Nigenda et al. 2003; Ministry of Health 2001a, 2001b).
\end{abstract}

Over the last decade, reforms have also been carried out within the national reproductive health programmes. In the late 1990s, the agreement reached at the 1994 International Conference on Population and Development in Cairo and at the 1995 World Conference on Women in Beijing, drew the attention of the international community towards women's sexual and reproductive needs and rights. Through changes in the official discourse, health policies, organisational structure and public institutions, a year after the Cairo meeting the Mexican government assumed some of the Conference's agreements. One of the main actions was the creation of the Family Planning and Reproductive Health Programme (Programa de Planificación Familiar y Salud Reproductiva) 1995-2000, which included actions in the areas of sexual education, family planning, mother-child health, and preventive health. The programme was designed by an inter-institutional group including public sector institutions and non-governmental organisations (NGOs) engaged with the issue of reproductive health. This group is integrated by the main actors involved in reproductive health decision making and service delivery, such as the Ministries of Health, Defence and Education, various social security bodies, the National Population Council, National Indigenist Institute, National Institute of Women, as well as several NGOs (González 1999; Espinosa and Paredes 2000). One of the main goals of the 1995-2000 National Programme of Sexual and Reproductive Programme (Programa Nacional de Salud Sexual y Reproductiva) was precisely to increase coverage of sexual and reproductive care, especially family planning coverage.

By focusing on two of the three strategies for extending health services coverage that followed the reform guidelines, this article develops a brief analysis of NGOs' influence on reproductive health policies intended to widen coverage in Mexico's health services. Those NGOs include some involved in service delivery and others in advocacy actions related to reproductive health. It starts by describing the evolution of citizen participation in the health sector, especially in the area of sexual and reproductive health. Then it presents some relevant examples of reform where citizen participation contributed to improve the coverage of sexual and reproductive health services.

\section{Citizen participation in reproductive health policies}

Collaboration between the government and NGOs for reproductive healthcare is a way to contribute to more efficient use of resources, improvement of quality and service delivery performance, and to using NGOs' experience in the matter. According to 
evidence from the international context, the priority of collaboration between the public and private sectors and civil society organisations is reaching higher efficiency; reducing redundancy of services and reaching economies of scale; creating a civic commitment and involving the community in efforts to solve problems and strengthen institutional capacity (Evans 1996; Lasker et al. 2001; Williams 2000; Gómez-Jauregui 2004b).

Civil society participation in the design and implementation as well as in service delivery in the field of population-related issues was approved in the 1994 Cairo conference's Programme of Action and signed by the Mexican government. The aim was:

to promote an effective partnership between all levels of Government and the full range of nongovernmental organizations and local community groups, in the decision making on the design of programmes relating to population, development and environment, as well as in its implementation, coordination, monitoring and evaluation of programmes. All that, in accordance with the general policy framework of Governments, taking duly into account the responsibilities and roles of the respective partners.

Governments were advised to both bring civil society into decision making and facilitate the contribution NGOs might give at all levels in solving problems related to population and development and, particularly, to guarantee the setting in motion of Cairo's Programme of Action (ICPD 1994).

In some Mexican states, following the Cairo conference, collaboration agreements between NGOs and distinct government tiers were established, although in a limited way. From 1995 onwards, the government considered the possibility of establishing such agreements with social organisations. The 1995-2000 National Development Plan establishes that:

the [current] legal framework is not enough to allow the development of the ideas and purposes of organized and independent society. The National Government sees it as highly important to promote a new regulatory framework that recognizes, favours, and encourages civil organizations' social, civic and humanitarian activities.
NGOs have also acknowledged joint work with the government as an option to continue the work they have carried out. Five years after the Cairo conference, a meeting was held with 200 representatives from organisations that promote women's health and rights in order to assess their achievements. That meeting tried to elaborate on the concept of 'partnership'. A document was drafted establishing, among other things, that 'such collaboration should stress government activities, rather than replacing their responsibility, in order to ascertain proper health care .... It also makes a call '... to governments as well as international and funding agencies to provide the general long-term support funds to strengthen women's organizational capability and their skills to effectively take part in governments' and agencies' decision-making, in programme implementation and evaluation as well' (Herrera 2000). In fact, the group of NGOs that take part in the National Forum for Health and Population Policies (Foro Nacional de Salud y Políticas de Población) established, during the board meeting on 6 August 2001, that the promotion of joint work between NGOs and government was one of their main demands.

Herrera (2000) describes four basic types of collaboration or interlocution in the case of Mexico: (1) NGO collaboration in consultancy, training, assessment, demand channelling, proposals, etc., with programmes that are initiatives and stay under full responsibility of the government in any of their stages; (2) government collaboration with actions that have historically belonged to NGOs, given the lack of public policies towards some problems; (3) mutual collaboration where both parts establish a formal collaboration agreement to carry out joint actions; and (4) successful political pressure, which is the first step in a process of feasible dialogue.

Tarrés (1998) stresses that collaboration between NGOs dedicated to women's issues and the government takes place in particular contexts. NGOs interested in establishing some kind of relation with the government do it based on previous friendship relations with officials or politicians, mostly women. There are few occasions when the relationship is established because the official sympathises with feminist theory or the NGO's work. The mobility typical of Mexico's public sector hampers continuity in collaboration agreements made under such circumstances. 
In the case of health policies, the Zedillo administration allowed the incorporation of several NGOs into the commissions in charge of the design of specific policies, such as reproductive health policies. However the inclusion was limited due to international pressure. One of these experiences that is worth mentioning is the Inter-Institutional Group on Reproductive Health (Grupo Interinstitucional de Salud Reproductiva), which includes members of the Education, Health, and Defence Departments, other health and social security public institutions, as well as NGOs and NGO networks (Espinosa and Paredes 2000). That inter-institutional group has continued working during the former and present administrations, and there are also equivalent groups in several states. That form of collaboration corresponds to one of the advocacy strategies used by women's NGOs and NGO networks in Latin America (Shepard 2003).

The Vicente Fox administration (2000-6), in turn, structured itself under the precedent of being the first opposition government in over 70 years. Since his campaign proposals, president Fox saw collaboration between government and civil organisations as an alternative in the design and implementation of social policies, including health policies. According to the proposal of the 2001-6 National Development Plan and the National Health Plan, decision-makers decided, at least at discourse level, to invest in collaboration between the government and civil organisations. The 2001-6 National Development Plan establishes that, 'in order to promote, preserve, and encourage Mexico's social wealth, the policy of social and human development includes social cohesiveness as the fourth of its core axes, since it proposes actions and programmes that tend ... to reduce the presence of the state in the aspects and areas where nongovernment organizations can make an effective contribution ...' (Federal Government 2001).

In the field of health, the appointment of Julio Frenk as Health Secretary also helped to bring civil society into decision making. In fact, one of the priority programmes of Frenk's administration was the Women and Health Programme (Programa Mujer y Salud, PROMSA), which created the National Consortium on Health and Women (Consorcio Nacional en Salud y la Mujer), although the National Consortium distinct sectors - including civil society organisations, engaged in the design and implementation of gender and women's health policies. Another important initiative for collaboration by the Health Department with NGOs was the Community Health Programme (Programa de Salud Comunitaria) (Gómez-Jauregui 2004a). In both programmes (PROMSA and the Community Health Programme), a call was made to fund community-level health projects. The operating mechanism and contract relation is very similar to the one NGOs establish with international agencies for funding: projects are submitted to a committee that selects the best ones; once selection is made, money is provided and thereafter, the organisation's work is regularly monitored (Gómez-Jauregui 2004a). In September 2003, the Women and Health Programme and the National Direction of Reproductive Health (Dirección General de Salud Reproductiva) were integrated, forming the National Centre for Gender Equity and Reproductive Health (Centro Nacional de Equidad de Género y Salud Reproductiva), taking on responsibility for the programmes that had been carried out by the two areas (Ministry of Health 2006).

One of the collaboration experiences that has had continuity, is with regard to Indesol within the National Development Department. Indesol was created to establish links among the different government tiers and civil society organisations, especially NGOs. The main interest is training and supporting poverty reduction programmes held by organised civil society. That is the only experience within the public sector that has institutionalised the relationship between the government and NGOs. However, as with the programmes of the Ministry of Health, they are mostly short-term agreements.

\section{NGO participation for widening coverage: key} examples

3.1 Incrementing the number and type of services to which the population has access

One common form of collaboration between NGOs and the government in the reproductive health field is advocacy actions, seen as all those strategies or actions designed to promote the implementation or reform of legal frameworks or public policies (Shepard 2003). In the case of sexual and reproductive health, that sort of interaction between NGOs and government has been determinant in designing and setting in motion intervention directed to solve important problems of reproductive health. In some cases, the advocacy experience has been 
able to establish important changes in health policies or legal frameworks, such as in the case of attention to victims of domestic violence and the inclusion of the method of emergency contraception in the basic set of public medications.

In the course of past administrations, NGOs have played an important role in the issue of domestic and sexual violence. Organisations that dealt with violence against women decided to engage in that issue because of the lack of state institutional response (Saucedo 1999). From the 1990s on, NGOs met several targets: drawing government attention to the problem; promoting legal changes; and influencing the design and start-up of public policies directed to the problem of violence against women (Saucedo 1999). The cases of Colima and Mexico City stand out in this process of NGOs' drawing government attention to the causes and consequences of domestic violence and influencing changes in law and in the design of policies to face that problem (Saucedo 1999; Gómez-Jauregui 2004b).

Nonetheless, towards the late 1990s agreements were established between the institutions that provide legal attention and those that provide medical care. During the past administration, the Mexican Official Norm (Norma Oficial Mexicana NOM-190-SSA), 'Health Service Provision: Criteria for Attention to Family Violence', was created as the result of the permanent advocacy work by NGOs on the issue of domestic violence. Those NGOs worked actively in its design and formulation. Only by 2001 an initiative is created at federal level to coordinate the participation of the health sector with other government bodies in order to provide assistance to victims of domestic violence through PROMSA. Another of PROMSA's important initiatives was that of working coordinately with NGOs dedicated to provide assistance, support, and refuge to victims of domestic violence (Secretaría de Salud 2006). Therefore, in some Mexican states, some assistance could be provided that the government itself was not able to provide.

Another successful initiative through which NGOs' involvement has incremented the number of state interventions in reproductive health, was the inclusion of emergency contraception as a method for family planning within the basic set of public medications. The project of a norm for family planning services, which included emergency contraception as an option was formulated in 1993, but it had stopped for several years. Ten years later, the health authorities requested the approval of the norm (Martín 2004). On 21 January 2004, the changes in the Family Planning NOM were published in the state official journal, incorporating three new contraceptive methods, including post-coital or emergency contraception. It was a process of analysis and debate that started in the 1990s, in which health sector institutions, scholars, international organisations, and NGOs took part (Mino 2005).

Even though emergency contraception is already included in the technical norm of family planning and within the basic set of public medications, which would presuppose the obligation by public health services to guarantee access to that family planning method to the whole population, it is not actually available. There are still right-wing organisations, members of the Catholic Church, and certain groups within the population that oppose the method and have put pressure on some public sector providers not to provide access to it. However, inclusion in the technical norm and in the basic set of medications is a way to institutionalise the use of that contraceptive method as a health policy and contribute to guarantee its long-term use.

\subsection{Taking services to geographical under-served population segments}

Before 2000, NGOs carried out most actions in service delivery and promotion in sexual and reproductive health for adolescents, which gave them experience and helped create innovative working models for that segment of the population. However their actions were mostly limited to very small groups in specific geographical areas. At the government's side, the 2001-6 National Plan of Reproductive Health (Plan Nacional de Salud Reproductiva) established, as one of its core targets, to provide reproductive health services to adolescents. Acknowledging the experience gained by NGOs in the area in the past 15 years, in order to meet that target, a proposal was presented to carry out joint actions with NGOs. Therefore, collaboration agreements have been established between NGOs and the government in that area of action since 2001

There are several examples of interventions that seek to deliver an increasing amount of sexual and reproductive services to a higher number of 
adolescents. NGOs working in that thematic area are not able to provide assistance or carry out actions that have large-scale effects on the adolescent population. In order to increase their action effects and as a strategy for inclusion of that kind of service into the public institutions of healthcare programmes, formal collaboration agreements have been established between NGOs and the government. Within such agreements, NGOs' role is that of training public sector personnel in proper strategies to provide adolescents with sexual and reproductive health. The IMSS-Oportunidades programme (that is the programme of the Mexican Institute of Social Security, or Instituto Mexicano del Seguro Social, intended to provide basic health services in rural areas to people that are not entitled to them) used NGOs' consultancy and training services to train youths as promoters in sexual and reproductive health at adolescent support centres in several Mexican states. It is a model for working with adolescents that had been promoted by organisations but which they were not able to take to a larger proportion of the population. Thus NGOs could broaden their area of influence by resorting to government's personnel and infrastructure, and the government is able to extend the coverage of health services to a segment that did not receive them (Gómez-Jauregui and Rico 2007).

\section{Scope and limits of NGO participation}

The three aforementioned cases have helped to successfully extend the coverage of sexual and reproductive health services. In the two first cases, by including interventions that the government did not carry out; and in the third case, by extending services to a specific segment of the population.

The interest of organisations in participating in sexual and reproductive health issues through advocacy and political pressure actions is as a result of the following: (1) the personal interest of their members on the issue, since that is the motto with which they carry their activism; (2) the lack of public policies and interest of the state towards guaranteeing access to sexual and reproductive health, which NGOs see as government responsibility; (3) it is a strategy that although gradually - helps to include themes into the government's agenda.

In cases of support to victims of domestic violence and the inclusion of the method of emergency contraception into the basic set of public medications, the long advocacy work by NGOs was able to raise government interest in actions and strategies of assistance that were not offered previously. Three additional factors have influenced that achievement: (1) personal interest by key decision-makers within the government in both issues; (2) the insistence by international organisations in the importance of incorporating actions directed to solving both problems into public services; and (3) the opportunity to institutionalise a set of initiatives by creating some technical norm on health, changing legislation, modifying policies, etc.

However, the strategy of NGOs' participation in the design and implementation of public policies can contribute to widening the effects of those policies along a certain timeframe. If collaboration between NGOs and the government is formally established through contracts or agreements, or if that policy is started and institutionalised by creating a technical norm, the increase in coverage is likely to have a longterm impact. In the case of collaboration of NGOs with IMSS-Oportunidades in the design and management of strategies for sexual and reproductive healthcare for adolescents, formal collaboration agreements have been established, but they were short-term ones. Participant organisations see that collaboration is an opportunity to scale-up their services to affect a higher percentage of the population. However this agreement was established due to the personal interest of key decision-makers from the IMSS-Oportunidades programme and not due to an institutional interest. The fact that the collaboration agreement includes training health personnel from IMSS-Oportunidades might contribute to guaranteeing the continuity of assistance strategies; however since such an agreement - even though it is formal - is a short-term one, that might restrict the permanence of those strategies when there are changes in government administration.

We can assume that the incorporation of civil society in decision making during the past two administrations is not likely to be reverted. From that perspective, the existing formal interaction between the government and civil society organisations in reproductive health issues might be seen as a state policy. The Inter-Institutional Group on Reproductive Health, created during the Zedillo administration, is an element of utmost importance for the design of reproductive health policies; a formally constituted body that survived the change in the political party in the government. The same happened in the case of 
Indesol, in which the support to civil society organisations is seemingly institutionalised. Furthermore, there are advocacy actions that have achieved important changes in health policies and legislation. Nevertheless, it is a gradual process, just as is the political transition. Both citizen participation in electoral processes together with the demand for transparency and the consolidation of oppositional political forces have developed since the second half

\section{References}

Espinoza, G. and Paredes, L. (2000) 'Salud Reproductiva en México. Los programas los procesos, los recursos financieros', in G. Espinoza (ed.), Compromisos y Realidades de la Salud Reproductiva en México, El Atajo Ed./UAM

Evans, P. (1996) 'Government Action, Social Capital and Development: Reviewing the Evidence on Synergy', World Development 24.6: 1119-32

Federal Government (2001) National Plan for Development 2001-2006, Mexico

Gómez-Dantés, Octavio; Gómez-Jauregui, Jesica and Inclán, Cristina (2004) 'La Equidad y la Imparcialidad en la Reforma del Sistema Mexicano de Salud' ['Equity and Fairness in the Mexican Health System Reform'], Salud Publica Mex 46: 399-416

Gómez-Jauregui, J. (2004a) 'The Feasibility of Government Partnerships with NGOs in the Reproductive Health Field in Mexico', Reproduction Health Matters 12.24: 42-55

Gómez-Jauregui, J. (2004b) 'Análisis del Origen, la Capacidad y la Posible Colaboración con el Gobierno de Organizaciones No Gubernamentales (ONGs) que Realizan Actividades de Salud Reproductiva en México' ['Analysis of the Origin, Capacity and Feasible Collaboration Agreements with Government of NGOs Working on Reproductive Health in Mexico'], PhD Thesis, National School of Public Health, Mexico

Gómez-Jauregui, J. and Rico, B. (2007) Capacity Gaps in Partnership Between Government and NGOs in Actions Intended to Advance Young People's Sexual and Reproductive Health and Rights, Final Report, project funded by MacArthur Foundation, Mexico

González, S. (1999) 'Los aportes de las ONGs a la Salud Reproductiva en México', in S. González (ed.), Las Organizaciones No-gubernamentales Mexicanas y la Salud Reproductiva, México: El Colegio de México of the 1980s, slowly but with no retrocession. Hopefully, spaces conquered by civil society will not be lost as long as we stay under transition towards a democratic system. That leads us to suppose that formally constituted spaces for interlocution between government and civil society organisations will not be lost either. However, the opening of new spaces with forms of collaborations not previously implemented will take place in the long run.

Herrera, C. (2000) Experiencias Viables de Colaboración Entre ONG de Mujeres e Instancias Gubernamentales en México [Viable Experiences of Collaboration Between Women's NGOs and Goverment Institutions in Mexico], Mexico City: Foro Nacional de Mujer y Políticas de Población Press [National Forum of Women and Population Policy]

International Conference on Population and Development (ICPD) (1994) Report of the International Conference on Population and Development, A/CONF.171/13, Cairo, 5-13 September

Lasker, R., Weiss, E. and Miller, R. (2001) 'Partnership Synergy: A Practical Framework for Studying and Strengthening the Collaborative Advantage', Milbank Quarterly 79.2: 179-205

Martín, Antonieta (2004) 'La Anticoncepción de Emergencia en América Latina y el Caribe', Rev Panam Salud Publica [Pan American Journal of Public Health] 16.6

Ministry of Health (2006) White Book: Woman and Health Program, Mexico: SSA, www.generoysalud reproductiva.gob.mx/Mujer_y_Salud-CNEGSR.pdf (accessed September 2007)

Ministry of Health (2001a) National Health Plan 2001-2006, Mexico: SSA, www.salud.gob.mx (accessed September 2003)

Ministry of Health (2001b) Reproductive Health Action Plan 2001-2006, Mexico: SSA. www.salud.gob.mx (accessed September 2003)

Mino, Fernando (2005) 'Anticoncepción de Emergencia, Segundo de Tiempo' ['Emergency Contraception, Second of Time. Conspiracy Against Free Choice'], En Letra S. Suplemento periódico La Jornada, 4 August, www.jornada.unam.mx/ 2005/08/04/Is-anticoncepcion. html (accessed September 2007)

Nigenda, Gustavo; Troncoso, Erika; Arreola, Héctor; Mariana, López and Luz, María González (2003) 'Mezcla Público-privada en el Sector Salud. 
Reflexiones Sobre la Situación en México' ['Public-Private Mix in Health. Reflections on the Mexican Situation'], Caleidoscopio de la Salud [Health Kaleidoscope], Mexico City: Funsalud Saucedo, Irma (1999) 'La Experiencia de las ONG en el Trabajo Sobre Violencia Sexual y Doméstica' ['NGO Working Experience in Sexual and Domestic Violence'], in S. González (ed.), Las Organizaciones No-gubernamentales Mexicanas y la Salud Reproductiva [Mexican Non-governmental Organizations and Reproductive Health], Mexico: El Colegio de México

Shepard, Bonnie (2003) 'NGO advocacy networks in Latin America: Lessons from experience in promoting women's and reproductive rights', The
North South Agenda Papers 61, North South Center, University of Miami, February Tarrés, M.L. (1998) 'Las Organizaciones no Gubernamentales: Avances de Investigación Sobre sus Características y Actuación' ['Nongovernmental Organizations: Research Progress on their Characteristics and Performance'], in J.L. Méndez (ed.), Organizaciones Civiles y Políticas Públicas en México y Centroamérica [Civil Organizations and Public Policy in Mexico and Central America], Mexico City: Miguel Angel Porrúa Williams, N. (2000) 'Modernising Government: Policy Networks, Competition and the Quest for Efficiency', Political Quarterly 71.4: 412-21 